\title{
Do Zinc Supplementation and Physical Exercise Affect Height, H/A z-score, and Academic Performance of Stunted Children in Coronavirus Disease 2019 Pandemic?
}

\author{
Nitta Isdiany* (iD, Holil Par'iD, Osman Syarief, Mamat Rahmat (D), Gurid Pramintarto Eko Mulyo (D) \\ Department of Nutrition, Poltekkes Kemenkes Bandung, Bandung, Indonesia
}

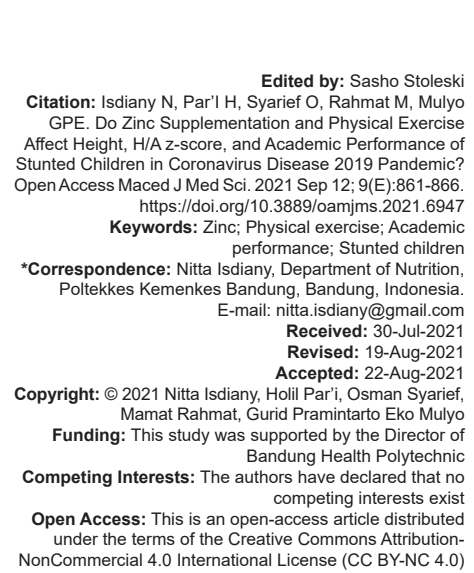

\section{Introduction}

Stunting is a child nutrition issue that mainly occurred in developing countries throughout the world [1]. The prevalence of stunting in children in Indonesia based on Riskesdas in 2010 was $35.4 \%$ [2]. Riskesdas in 2018 reported that the prevalence of stunting in children declined to $23.6 \%$ in Indonesia and $22.8 \%$ in West Java province. Despite the decline, the condition remains concerning considering that children should have optimal growth to be qualified adult human resources in the future [3].

Stunting is a chronic growth disorder, characterized by children's height in which case is shorter than children of their age. Stunting indicates failure of children's growth as it has happened since early of their age. Several factors can influence stunting. However, the coronavirus disease 2019 (COVID-19) outbreak might be one obstacle for families infected by the virus to deal with stunting [4]. Stunting has become an indicator of the nutritional issue in children due to inadequate intake of nutrients for a long time or accompanied by recurrent infectious disease. Limitation of mobility during the COVID-19 pandemic in Indonesia has impacted the families' socioeconomic, which results in the limited availability of food consumption for family members, including stunted children [1]. The impact of stunting continues into adulthood with shorter height, risk of chronic diseases, low achievements, and low income [5]. Stunted children experience deficiency of certain nutrients, therefore their brain cells have not reached their optimal development and are irreversible, which, in turn, inhibit children's potential for complete development [4].

A study in Malang, Indonesia, suggested a significant correlation between dietary intake of zinc sources and hair zinc level in stunted children in primary school [6]. A study in Lampung, Indonesia, proved that stunted children had lower serum zinc levels than non-stunted children [7]. Taking zinc supplementation intends to meet the need for zinc; however, the impact of the program has not been effective. A cohort study in the Philippines found that non-stunted children had a greater chance of finishing school than stunted children. There was a strong relationship between the 
$\mathrm{H} / \mathrm{A}$ z-score at the beginning of children's lives and the length of school year achieved by the children [8].

The slow decline in the prevalence of stunting in Asian countries requires an integrated and comprehensive program mechanism [4]. A study in rural Ethiopia with $10 \mathrm{mg}$ of zinc supplementation for 6 months increased the linear growth of children, and the increase was greater in stunted children than non-stunted children [9]. There was also a significant difference in height between treatment group provided with $10 \mathrm{mg}$ of zinc supplementation 6 days/week for 7 months and placebo group based on a study conducted in Yasuj, Southwest of Iran [10]. A study in Thailand with $15 \mathrm{mg}$ of zinc supplementation for 6 months in children suggested that the treatment group had a significant increase in height and z-score than the control group. Providing zinc supplementation for 6 months improved the linear growth of children; however, there was no significant difference in other anthropometric parameters [11].

Thus far, studies on zinc supplementation in stunted children remain limited in number and have been carried out in the non-pandemic situation. In addition to zinc supplementation, there is also very limited study on physical exercise and academic performance in stunted children who are studying from home during the COVID-19 outbreak. The novelty of this study includes the combination of zinc supplementation and physical exercise in stunted children and the observation of its effect on the growth and academic performance of stunted children in the COVID-19 pandemic. The purpose of this study was to analyze the effect of zinc supplementation and physical exercise on height, H/A z-score, and academic performance of stunted children in the COVID-19 pandemic.

\section{Methods}

\section{Research design}

This study used a randomized pre-posttest control group design. The population includes all students of SDN Cipageran Mandiri 1, North Cimahi, Indonesia, in the 2020/2021 academic year.

\section{Sampling technique}

The sample was stunted children with inclusion criteria of being a 2-6 grader, H/A z-score < -2 SD, willing to participate through parental consent; and exclusion criteria of suffering from chronic diseases/ disorders. The number of samples was determined using an experimental design formula for 2 groups [12].

There was an addition of $30 \%$ as anticipation of participants dropping out; therefore, each group consisted of 15 children. The participants were divided into two groups, including the treatment group and the control group. The treatment group was provided with $5 \mathrm{ml}$ of zinc syrup 3 times/week for 3 months and practiced physical exercise 3 times/week for 3 months. The control group only practiced physical exercise 3 times/week for 3 months. The exercise was physical fitness for elementary school students using a video. The exercise was monitored by the researchers and the teacher on WhatsApp Group. The COVID-19 outbreak could not allow the researchers to conduct the experiment for more than 3 months.

\section{Data collection technique}

The research assistants visited each participant's house by implementing health protocol to meet the parents to provide the zinc supplementation to their children as recommended. Supplementation of $5 \mathrm{ml}$ of zinc syrup contained $20 \mathrm{mg}$ of zinc in the form of zinc sulfate monohydrate syrup. Monitoring and evaluating the takings of zinc syrup supplementation were carried out online through WhatsApp Group. Physical exercise intervention in the form of physical fitness exercise was practiced online using videos sent by the sports teacher on WhatsApp Group. Each child practiced the exercise at their respective houses and sent photos during the exercise. Studying from home during the COVID-19 pandemic limits the direct meetings between the researchers and the participants to practice the physical exercise together.

The research assistants measured the participants' height before and after the intervention at their respective houses by implementing health protocol using a microtome with an accuracy of $0.1 \mathrm{~cm}$. Analyzing the H/A z-score used the World Health Organization (WHO) AnthroPlus software version 1.0.4. The dietary intake data (protein, zinc, calcium) were collected using a 24-h recall method through telephone and messages on the WhatsApp Group. Analysis of nutrients was performed using the 2017 Indonesian Food Composition Table. The academic performance data were the average scores of Mathematics and Indonesian subjects, taken from the midterm exam for the preliminary data and the final examination for the final data. The collection of academic performance data was carried out by interviewing the participants' parents about the scores received from the school.

\section{Data analysis}

The difference of characteristics between the treatment group and control group was analyzed using the Chi-square test. The data were normally distributed based on the Kolmogorov-Smirnov test, therefore analysis of the difference in average height, $\mathrm{H} / \mathrm{A}$ z-score, and academic performance before and after the intervention in each group used paired t-test 
and the difference between the two groups used an independent t-test.

\section{Ethical clearance}

This study has received an Ethical Clearance from the Health Research Ethics Committee of the Health Polytechnic of the Ministry of Health in Bandung no. 07/KEPK/EC/2020.

\section{Results}

\section{Participants characteristics}

Participants in both groups had nearly similar average age which was $10.04(+1.53)$ years in the treatment group and $10.42(+1.59)$ years in the control group. Statistically, there was no difference in age between the treatment group and the control group ( $p>0.05$ ). Sample distribution based on other characteristics is illustrated in Table 1.

Table 1: Sample Distribution Based on Characteristics

\begin{tabular}{|c|c|c|c|c|c|}
\hline \multirow[t]{2}{*}{ Characteristics } & \multicolumn{2}{|c|}{ Treatment Group } & \multicolumn{2}{|c|}{ Control Group } & \multirow{2}{*}{ Sig. } \\
\hline & $\mathrm{n}(15)$ & $\%$ & $\mathrm{n}(15)$ & $\%$ & \\
\hline \multicolumn{6}{|l|}{ Gender } \\
\hline Male & 8 & 53.3 & 5 & 33.3 & \multirow[t]{2}{*}{0.461} \\
\hline Female & 7 & 46.7 & 10 & 66.7 & \\
\hline \multicolumn{6}{|c|}{ Father's level of education } \\
\hline Primary & 8 & 53.3 & 10 & 66.7 & \multirow[t]{2}{*}{0.709} \\
\hline Secondary & 7 & 46.7 & 5 & 33.4 & \\
\hline \multicolumn{6}{|c|}{ Mother's level of education } \\
\hline Primary & 9 & 60.0 & 12 & 80.0 & \multirow[t]{2}{*}{0.427} \\
\hline Secondary & 6 & 40.0 & 3 & 20.0 & \\
\hline \multicolumn{6}{|c|}{ Father's employment } \\
\hline Unemployed & 2 & 13.3 & 1 & 6.7 & \multirow[t]{2}{*}{1.000} \\
\hline Employed & 13 & 86.7 & 14 & 93.4 & \\
\hline \multicolumn{6}{|c|}{ Mother's employment } \\
\hline Unemployed & 11 & 73.3 & 13 & 86.7 & \multirow[t]{2}{*}{0.651} \\
\hline Employed & 4 & 26.7 & 2 & 13.4 & \\
\hline
\end{tabular}

The number of male children was greater in the treatment group (53.3\%) than in the control group $(33.3 \%)$. In number, there were fewer female children in the treatment group (46.7\%) than in the control group $(66.7 \%)$. The result of the Chi-square test proved that there was no significant difference in gender between treatment and control groups $(p>0.05)$.

The number of fathers with primary education in the treatment group $(53.3 \%)$ was less than in the control group $(66.7 \%)$. The Chi-square test showed that there was no significant difference in the father's level of education between treatment and control groups ( $p>0.05$ ). The number of mothers with primary education in the treatment group $(60.0 \%)$ was less than in the control group (80.0\%). Fisher's exact test showed that there was no significant difference in mother's level of education between treatment and control groups $(p>0.05)$.

The number of unemployed fathers was greater in the treatment group $(13.3 \%)$ than in the control group $(6.7 \%)$. The result of Fisher's exact test showed that there was no significant difference in father's employment between treatment and control groups ( $p>0.05)$. The number of unemployed mothers was less in the treatment group $(73.3 \%)$ than in the control group $(86.7 \%)$. The result of Fisher's exact test showed that there was no significant difference in mother's employment between treatment and control groups ( $p>0.05)$.

\section{Nutrient intake}

Table 2 describes that the intake of energy, protein, zinc, and Ca from foods consumed daily was nearly similar between treatment and control groups. The result of the independent t-test showed that there was no significant difference in the average intake of energy, protein, zinc, and $\mathrm{Ca}$ between treatment and control groups $(p>0.05)$

Table 2: Sample Distribution Based on Nutrient Intake

\begin{tabular}{llll}
\hline Nutrient intake & Treatment Group (Mean \pm SD) & Control Group (Mean \pm SD) & Sig. \\
\hline Energy $(\mathrm{kcal})$ & $953.69 \pm 196.49$ & $1038.63 \pm 247.32$ & 0.307 \\
Protein $(\mathrm{g})$ & $39.36 \pm 13.01$ & $36.71 \pm 9.94$ & 0.537 \\
Zinc $(\mathrm{mg})$ & $3.79 \pm 1.55$ & $3.79 \pm 1.30$ & 1.000 \\
$\mathrm{Ca}(\mathrm{mg})$ & $213.33 \pm 156.96$ & $164.08 \pm 115.41$ & 0.336 \\
\hline Independent t-test: not significant $(\mathrm{p}>0.05)$. & &
\end{tabular}

The intake of energy, protein, zinc, and $\mathrm{Ca}$ in treatment and control groups did not meet the 2019 Recommended Dietary Allowance (RDA) for children aged 10-12 years [13]. Energy intake in the treatment group only met $50.19 \%$ of RDA and in the control group by $54.66 \%$. The protein intake in the treatment group met $75.69 \%$ of the protein RDA and in the control group by $70.59 \%$. Zinc intake in both treatment and control groups only met $47.3 \%$ of the zinc RDA. Ca intake was significantly low in both groups, in which $\mathrm{Ca}$ intake in the treatment group only met $17.77 \%$ of the Ca RDA and in the control group by $13.67 \%$.

Table 3: Change in Average Height Pre-Post Intervention

\begin{tabular}{llllll}
\hline Group & Mean (Pre) & Mean (Post) & Sig $^{\text {a }}$ & Change $(\Delta)$ & Sig. $^{.}$ \\
\hline Treatment & 121.6 & 123.7 & $0.000^{*}$ & 2.1 & 0.469 \\
Control & 125.2 & 126.9 & $0.000^{*}$ & 1.72 & \\
\hline
\end{tabular}

\section{Change in average height}

As illustrated on Table 3 , in the treatment group, there was a significant difference in the increase in average height before and after the intervention $(p<$ 0.05). In the control group, there was also a significant difference in the increase in average height before and after the intervention ( $p<0.05)$. The increase in average height in the treatment group was $2.10 \mathrm{~cm}$ and in the control group was $1.72 \mathrm{~cm}$. However, there was no significant difference in the increase in average height between treatment and control groups $(p>0.05)$.

\section{Change in average Z-score of $H / A$}

As seen from Table 4, in the treatment group, the average $\mathrm{z}$-score of $\mathrm{H} / \mathrm{A}$ increased by 0.19 from -2.62 to -2.43 . The result of paired t-test suggested that there 
was a significant difference in the average z-score of $\mathrm{H} / \mathrm{A}$ before and after intervention in the treatment group $(p<0.05)$. This indicates that providing $20 \mathrm{mg}$ of zinc 3 times/week with physical exercise 3 times/week for 3 months can increase H/A Z-score in stunted children.

Table 4: Change in average Z-Score of $\mathrm{H} / \mathrm{A}$ pre-post intervention

\begin{tabular}{|c|c|c|c|c|c|}
\hline Group & Mean (Pre) & Mean (Post) & $\mathrm{Sig}^{\mathrm{a}}$ & Change $(\Delta)$ & Sig. ${ }^{b}$ \\
\hline Treatment & -2.62 & -2.43 & $0.022^{*}$ & 0.19 & 0.572 \\
\hline Control & -2.43 & -2.29 & $0.009^{*}$ & 0.14 & \\
\hline
\end{tabular}

In the control group, there was an increase in the average $\mathrm{z}$-score of $\mathrm{H} / \mathrm{A}$ by 0.14 from -2.43 to -2.29 . The result of paired t-test showed that there was a significant difference in the average z-score of $\mathrm{H} / \mathrm{A}$ before and after intervention in the treatment group $(p<0.05)$. This indicates that physical exercise 3 times/week for 3 months can increase H/A Z-score in stunted children. Despite a tendency for an increase in the average $\mathrm{z}$-score of $\mathrm{H} / \mathrm{A}$ in the treatment group (0.19) which was higher than in the control group (0.14), the result of the independent t-test showed that the mean difference was not significant $(p>0.05)$.

\section{Change in average academic performance}

As described in Table 5, in the treatment group, the average score of performance decreased from 80.20 before the intervention to 79.41 after the intervention. However, the result of paired t-test showed no significant difference in the average academic performance score before and after intervention in the treatment group ( $p>0.05$ ). In the control group, the average academic performance score was nearly similar before and after the intervention, which was 79.58 and 79.93 , respectively.

Table 5: Change in average academic performance before and after intervention

\begin{tabular}{|c|c|c|c|c|c|}
\hline Group & Mean (Pre) & Mean (Post) & Sig. ${ }^{a}$ & Change $(\Delta)$ & Sig. ${ }^{\circ}$ \\
\hline Treatment & 80.20 & 79.41 & 0.649 & -0.79 & 0.549 \\
\hline Control & 79.58 & 79.93 & 0.665 & 0.35 & \\
\hline
\end{tabular}

The result of paired t-test proved that there was no significant difference in the average academic performance score before and after the intervention in the control group $(p>0.05)$. The result of the independent t-test showed that there was no significant difference in the change in average academic performance scores between treatment and control groups ( $p>0.05)$.

\section{Discussion}

The result of this study indicates that the tendency for a change in the average height was greater in the treatment group $(2.1 \mathrm{~cm})$ than in the control group $(1.72 \mathrm{~cm})$. However, there was no statistically significant difference in the change in average height between treatment and control groups. This contradicts a study on stunted toddlers in Surakarta, Indonesia, which found that there was a difference in height after being provided with $20 \mathrm{mg}$ of zinc supplementation 2 times a week for 3 months [14]. The difference between studies is due to the difference in the population, the intervention in which case the provision of zinc supplementation was not followed by physical exercise, and the study was conducted in the non-pandemic situation, which was before the COVID-19 outbreak.

Another study in Thailand conducted on a similar population, which was children, proved that zinc supplementation provided for 6 months increased the linear growth of children. The increase in height was significantly higher $(5.6 \mathrm{~cm})$ in the treatment group than in the control group $(4.7 \mathrm{~cm})$ [11]. Another study on children in Yasuj, Southwest of Iran, with zinc supplementation provided for 7 months showed a significant difference in the increase in height between treatment and control groups. Zinc supplementation increased linear growth with a mean of $3.26 \mathrm{~cm}$ in the treatment group and $1.65 \mathrm{~cm}$ in the control group [10]. The increase in height in this study was lower than the results of the two studies. This is due to the shorter length of zinc supplementation intervention in this study, which was only 3 months, and the length of intervention in other studies was at least 6 months.

The result of another study conducted in Iran on children aged 6.5-10 years showed that there was a significant effect of single zinc supplementation provided for 6 months on the change in children's height. The average height gain was $2.87 \mathrm{~cm}$ [15]. The difference with the result of this study is due to the difference in length of intervention, the population in which case was not limited to stunted children, intervention in the control group in which case was a placebo, and timing in which case was conducted before the COVID-19 outbreak.

The result of this study also differs from a study conducted on stunted toddlers in Pati Regency, Indonesia. The study suggested that there was a significant difference in height gain between stunted toddlers provided with zinc supplements and the control group. The average height gain in the treatment group was $3.35 \mathrm{~cm}$ and the control group was $1.0 \mathrm{~cm}$ [16]. The difference with the result of the study is due to the difference in population and intervention in the control group in which case was a placebo.

The growth of children's height is strongly affected by bone growth. A nutrient that affects bone growth is calcium. The participants' calcium intake is very low both in the intervention and control groups. Physical exercise affects the absorption of calcium used for bone growth. In addition, zinc also plays a role in stimulating children's growth. Participants' zinc intake from daily food consumption is significantly low; therefore, it does not meet the zinc adequacy ratio for children. The provision of zinc supplementation in this study contributed to an increase in zinc intake 
in the treatment and control groups. However, the short length of intervention, which was 3 months, with physical exercise in the treatment group did not show a significant difference between the two groups.

The result of this study differs from the study conducted in Thailand, in which case after 6 months provided with supplementation, there was a significant difference in the $\mathrm{H} / \mathrm{A}$ z-score between the treatment group $(0.45+0.37)$ and control group $(0.37+0.27)[11]$. Meanwhile, the result of this study found that there was a tendency for an increase in the $\mathrm{H} / \mathrm{A}$ z-score in the treatment group, which was greater than in the control group. However, the independent t-test showed no significant difference in the change in average $\mathrm{z}$-score of $\mathrm{H} / \mathrm{A}$ between treatment and control groups $(p>0.05)$.

Zinc is a micromineral that can stimulate children's growth hormones to reach their optimal function. The role of zinc in growth is closely related to the increase in plasma concentrations of Insulin-like Growth Factor I (IGF-I). IGF-I factor is a growth hormone mediator that plays a role as a growth-promoting factor in children's growth process [17].

Optimizing children's growth can be achieved by physical exercise adjusted to the age level of children, including 7-8 years (grade 1-2), 9 years (grade 3 ), 10-11 years (grade $4-5$ ), and $12-13$ years (grade 6) [18]. Result of a study conducted before the COVID-19 outbreak found that there was a significant relationship between nutritional status, physical activity, and physical fitness level of Al-Hikmah Gempolmanis elementary school students in Indonesia [19]. A study of stunted children aged 6-15 years in Peru suggested that stunting affects the fitness level of stunted children [20].

In this study, the physical exercise intervention did not differentiate participants' age or class. All participants were provided with the same physical exercise intervention in the form of physical fitness exercise, which might not be appropriate as it did not differentiate children's age or class. This did not have an impact on stimulating the optimal height or growth of the H/A z-score. The length of intervention in this study was 3 months and it did not succeed to maximize the impact of the intervention on the research outcomes. In addition, the limited space for participants to practice physical exercise in their respective houses due to the COVID-19 outbreak has made the exercise less effective. Stunting in this population might affect the level of fitness in doing physical exercise.

A study suggested that stunting in children affects their cognitive development and academic performance. This is associated with impaired brain neuron maturity, structure, and function that results in permanent damage to cognitive development [21]. The result of this study showed that there was no significant difference in the change in average academic performance scores between treatment and control groups. This is related to the COVID-19 outbreak which requires students to study from home guided by their parents, and the implementation is less effective. The academic performance of the participants may not be entirely the result of finishing assignments independently. This might be that when students are doing their assignments, they can look up the answers on the books or be guided by their parents. Studying in the COVID-19 pandemic is a limitation of this study as it cannot picture the actual academic performance of students as in the nonpandemic situation in schools.

Another study conducted in Makassar, Indonesia, reported that there was a significant relationship between the level of physical fitness and academic performance of non-stunted children in primary schools [22]. A similar condition may occur in stunted children in this study. The result of this study suggested that there was no significant difference in the level of physical exercise compliance in treatment and control groups. Stunted children who practice physical exercise regularly have an impact on physical fitness which, in turn, affects their thinking ability to achieve academic performance at school. However, it requires an in-depth study as other factors affect academic performance.

\section{Conclusion}

There is no significant difference in height, $\mathrm{H} / \mathrm{A}$ z-score, and academic performance between stunted children provided with zinc supplementation and physical exercise for 3 months and stunted children provided only with physical exercise intervention in the COVID19 pandemic. The further study requires a longer length of intervention for a minimum of 6 months to determine the effect of zinc supplementation and physical exercise on the growth and academic performance of stunted children in the non-pandemic period.

\section{Acknowledgment}

Thank you to the Director of Bandung Health Polytechnic for funding this research. Thank you to enumerators for collecting data for this research.

\section{References}

1. Global Nutrition Report. The Global Nutrition Report's Independent Expert Group. India: Global Nutrition Report; 2020. 


$$
\text { p. } 168 .
$$

2. Kartono D, Fuada N, Budi Setyawati D. Stunting Among SchoolAge Children in Indonesia By Characteristics of Family. Penelit Gizi dan Makanan. 2013;36(2):121-6. https://doi.org/10.22146/ ijcn.23109

3. Riset Kesehatan Dasar. Badan Penelitian dan Pengembangan Kesehatan; 2018. p. 221-2. Available from: http://www.labdata. litbang.kemkes.go.id/images/download/laporan/rkd/2018/ laporan_nasional_rkd2018_final.pdf. [Last accessed on 2021 May 09].

4. World Health Organization. Reducing Stunting in Children. Equity Considerations for Achieving the Global Nutrition Targets 2025. Geneva: World Health Organization; 2018. p. 40. Available from: https://www.apps.who.int/iris/bitstream/han dle/10665/260202/9789241513647-eng.pdf?sequence=1. [Last accessed on 2021 May 09].

5. Beckmann J, Lang C, du Randt R, Gresse A, Long KZ, Ludyga S, et al. Prevalence of stunting and relationship between stunting and associated risk factors with academic achievement and cognitive function: A cross-sectional study with South African primary school children. Int J Environ Res Public Health. 2021;18(8):4218. https://doi.org/10.3390/ijerph18084218 PMid:33923436

6. Rani N, Diffah H, Sapja A. The correlation between zinc source dietary intake dan hair's zinc level on stunting incidence at primary school students of malang regency. IEESE Int J Sci Technol. 2017;6(2):1-5.

7. Berawi KN, Hidayati MN, Susianti S, Perdami RR, Susantiningsih T, Maskoen AM. Decreasing zinc levels in stunting toddlers in Lampung Province, Indonesia. Biomed Pharmacol J. 2019;12(1):239-43. https://doi.org/10.13005/bpj/1633

8. Adair LS, Carba DB, Lee NR, Borja JB. Stunting, IQ, and final school attainment in the cebu longitudinal health and nutrition survey birth cohort. Econ Hum Biol. 2021;42:100999. https://doi. org/10.1016/j.ehb.2021.100999

\section{PMid:33865193}

9. Umeta WM. Role of zinc in stunting of infants and children in rural Ethiopia. In: Role zinc Stunting Infants Child Rural Ethiop; 2003. p. 117. Available from: http://www.cabdirect.org/ abstracts/20033053319.html. [Last accessed on $2021 \mathrm{Jul} 04$ ].

10. Ebrahimi S, Pormahmodi A, Kamkar A. Study of zinc supplementation on growth of schoolchildren in Yasuj, Southwest of Iran. Pak J Nutr. 2006;5(4):341-2.

11. Rerksuppaphol S, Rerksuppaphol L. Zinc supplementation enhances linear growth in school-aged children: A randomized controlled trial. Pediatr Rep. 2017;9(4):7294. https://doi. org/10.4081/pr.2017.7294

\section{PMid:29383221}

12. Chow SC, Wang H, Shao J. Sample Size Calculations in Clinical Research. $2^{\text {nd }}$ ed. London, United Kingdom: Chapman and Hall/CRC Biostatistics Series; 2007. p. 480. Available from: http://www.amazon.com/calculations-clinical-research-editionbiostatistics/dp/1584889829. [Last accessed on 2021 Jul 04]. https://doi.org/10.1201/9780203911341.ch11

13. Kemenkes RI. Angka Kecukupan Gizi Mayarakat Indonesia. Menteri Kesehat Republik Indones Peratur Menteri Kesehat Republik Indones. Vol. 65. Indonesia: Kemenkes RI; 2019. p. 2004-6.

14. Kusudaryati DP. The Difference in Height Difference Before and After Zn Supplementation in Stunting Toddlers. Profesi. 2015;12:53-7. https://doi.org/10.26576/profesi.130

15. Vakili R, Bakhsh MY, Vahedian M, Mahmoudi M, Saeidi M, Vakili S. The effect of zinc supplementation on linear growth and growth factors in primary schoolchildren in the suburbs Mashhad, Iran. Int J Pediatr. 2015;3(2):1-7.

16. Kasanah $U$, Muawanah $S$. The effectiveness of zinc supplementation in increasing stunted children's height in Pati district. Coping Community Publ Nurs. 2020;8(3):251. https:// doi.org/10.24843/coping.2020.v08.i03.p05

17. Hidayati MN, Perdani RR, Karima N. The Role of Zinc in Children Growth. Majority. 2019;8:168-71.

18. Burhaein E. The Effectiveness of Zinc Supplementation in Increasing Stunted Children's Height in Pati District. Indones J Prim Educ. 2017;1(1):51-8. https://doi.org/10.17509/ijpe. v1i1.7497

19. Azizin I. Hubungan status gizi dan aktivitas fisik dengan tingkat kebugaran jasmani siswa sekolah dasar. J Kesehat Olahraga. 2014;2(2):17-22. Available from: https://www.jurnalmahasiswa. unesa.ac.id/index.php/jurnal-kesehatan-olahraga/article/ view/8107/8329. [Last accessed on 2021 Jul 04]. https://doi. org/10.36526/kejaora.v4i2.705

20. Santos C, Bustamante A, Vasconcelos O, Pereira S, Garganta R, Tani G, et al. Stunting and physical fitness. The peruvian health and optimist growth study. Int J Environ Res Public Health. 2020;17(10):3440. https://doi.org/10.3390/ijerph17103440 PMid:32429040

21. Yadika AD, Berawi KN, Nasution SH. The Effect of Stunting on Cognitive Development and Learning Achievement. J Major. 2019;8(2):273-82.

22. Kamaruddin I. Analysis of the Level of Physical Freshness on the Learning Achievement of State Elementary School Students Bawakaraeng III Makassar. Sport J Phys Educ Sport Recreat. 2018;1(2):85. https://doi.org/10.26858/sportive.v1i2.6393 